\title{
Larvicide potential of essential oils from Brazilian plants against Aedes aegypti
}

\author{
Potencial larvicida de óleos essenciais de plantas brasileiras contra o Aedes aegypti \\ Potencial larvicida de aceites esenciales de plantas brasileñas contra el Aedes aegypti
}

Received: 01/25/2022 | Reviewed: 01/30/2022 | Accept: 02/02/2022 | Published: 02/05/2022

\author{
Madalena Machado Rocha \\ ORCID: https://orcid.org/0000-0002-4592-6988 \\ Federal University of São Francisco Valley, Brazil \\ E-mail: madalena.rocha@ discente.univasf.edu.br \\ Raquel Deodato Silva Rodrigues \\ ORCID: https://orcid.org/0000-0003-0021-8598 \\ Federal University of São Francisco Valley, Brazil \\ E-mail: deodatoraquel@hotmail.com \\ Pedro Henrique Vieira Guimarães \\ ORCID: https://orcid.org/0000-0002-3176-7488 \\ Federal University of São Francisco Valley, Brazil \\ E-mail: pedrovieirahg@gmail.com \\ Joyce Kelly Marinheiro da Cunha Gonsalves \\ ORCID: https://orcid.org/0000-0002-1559-4249 \\ Federal University of São Francisco Valley, Brazil \\ E-mail: joyce.gonsalves@ univasf.edu.br
}

\begin{abstract}
The arboviruses Dengue, Chikungunya and Zika virus are present in several tropical regions and are transmitted by the Aedes aegypti mosquito. The containment of these diseases is done by fighting the vector, usually using chemical insecticides, such as organophosphates and organochlorines. These provoke the resistance of the transmitter, have a high accumulation rate in the body of non-target populations, and promote the contamination of ecosystems. The application of materials of natural origin with larvicidal activity, such as essential oils, is a promising alternative to replace the use of chemical insecticides. In this systematic review, we sought to present the larvicidal properties of essential oils from botanical species of Brazilian flora against Ae. aegypti. The search resulted in 36 papers selected as articles of interest. The 65 plants described in the selected articles showed larvicidal activity mostly excellent ( 27 were classified as strongly active) or satisfactory (13 were moderately active, and 24 were effective), while only one was inactive. The species that showed the highest larvicidal activity were: Anacardium occidentalis L. (0.01 ppm); Copaifera langsdorffii Desf. (0.04 ppm); Carapa guianensis Aubl. (0.06 ppm); Cymbopogon winterianus Jowitt. (0.10 ppm); Ageratum conyzoides L. (0.15 ppm); Tagetes minuta L. (0.21 - $0.25 \mathrm{ppm})$; and Siparuna guianensis Aubl. (1.76, 0.98 and $2.46 \mathrm{ppm})$. Studies on the essential oils of Brazilian plants are of great relevance to combat arboviruses. The Brazilian flora, despite its vast biodiversity, is still little known and explored, possessing a huge potential for the development of eco-friendly, environmentally safe, and low-cost products.
\end{abstract}

Keywords: Aedes aegypti; Arboviruses; Larvicides; Brazilian flora; Essential oils.

\section{Resumo}

As arboviroses Dengue, Chikungunya e Zika vírus estão presentes em várias regiões tropicais e são transmitidos pelo mosquito Aedes aegypti. A contenção destas doenças é feita pelo combate ao vetor, geralmente utilizando inseticidas químicos, como organofosforados e organoclorados. Estes provocam a resistência do transmissor, têm uma alta taxa de acúmulo no corpo de populações não-alvo e promovem a contaminação dos ecossistemas. A aplicação de materiais de origem natural com atividade larvicida, tais como óleos essenciais, é uma alternativa promissora para substituir o uso de inseticidas químicos. Nesta revisão sistemática, procuramos apresentar as propriedades larvicidas dos óleos essenciais de espécies botânicas da flora brasileira contra o Ae. aegypti. A pesquisa resultou em 36 artigos selecionados como artigos de interesse. As 65 plantas descritas nos artigos selecionados mostraram atividade larvicida em sua maioria excelente ( 27 foram classificadas como fortemente ativas) ou satisfatória ( 13 foram moderadamente ativas, e 24 foram efetivas), enquanto apenas uma foi inativa. As espécies que apresentaram a maior atividade larvicida foram: Anacardium occidentalis L. (0,01 ppm); Copaifera langsdorffii Desf. (0,04 ppm); Carapa guianensis Aubl. (0,06 ppm); Cymbopogon winterianus Jowitt. (0,10 ppm); Ageratum conyzoides L. (0,15 ppm); Tagetes minuta L. (0,21 - 0,25 ppm); e Siparuna guianensis Aubl. (1,76, 0,98 e 2,46 ppm). Os estudos sobre os óleos essenciais das plantas brasileiras são de grande relevância para combater as arboviroses. A flora brasileira, apesar de sua vasta biodiversidade, ainda é pouco conhecida e explorada, possuindo um enorme potencial para o desenvolvimento de produtos ecologicamente corretos, ambientalmente seguros e de baixo custo.

Palavras-chave: Aedes aegypti; Arboviroses; Larvicidas; Flora brasileira; Óleos essenciais. 


\begin{abstract}
Resumen
Las arboviroses Dengue, Chikungunya y Zika virus están presentes en varias regiones tropicales y son transmitidos por el mosquito Aedes aegypti. La contención de estas enfermedades se realiza combatiendo el vector, generalmente con insecticidas químicos, como los organofosforados y los organoclorados. Estos provocan la resistencia del transmisor, tienen una alta tasa de acumulación en el cuerpo de las poblaciones no objetivo y promueven la contaminación de los ecosistemas. La aplicación de materiales de origen natural con actividad larvicida, como los aceites esenciales, es una alternativa prometedora para sustituir el uso de insecticidas químicos. En esta revisión sistemática, buscamos presentar las propiedades larvicidas de los aceites esenciales de especies botánicas de la flora brasileña contra Ae. aegypti. La búsqueda dio como resultado 36 artículos seleccionados como artículos de interés. Las 65 plantas descritas en los artículos seleccionados mostraron una actividad larvicida en su mayoría excelente (27 fueron clasificadas como fuertemente activas) o satisfactoria (13 fueron moderadamente activas y 24 fueron eficaces), mientras que sólo una fue inactiva. Las especies que mostraron la mayor actividad larvicida fueron: Anacardium occidentalis L. (0,01 ppm); Copaifera langsdorffii Desf. (0,04 ppm); Carapa guianensis Aubl. (0,06 ppm); Cymbopogon winterianus Jowitt. (0,10 ppm); Ageratum conyzoides L. (0,15 ppm); Tagetes minuta L. (0,21 - 0,25 ppm); y Siparuna guianensis Aubl. (1,76, 0,98 y 2,46 ppm). Los estudios sobre los aceites esenciales de las plantas brasileñas son de gran relevancia en la lucha contra las arbovirosis. La flora brasileña, a pesar de su enorme biodiversidad, es todavía poco conocida y explorada, y posee un enorme potencial para el desarrollo de productos ecológicamente correctos, ambientalmente seguros y de bajo coste.
\end{abstract}

Palabras clave: Aedes aegypti; Arboviroses; Larvicidas; Flora brasileña; Aceites esenciales.

\title{
1. Introduction
}

Dengue, Chikungunya and Zika viruses are the main arboviruses present in tropical countries, transmitted by the Aedes aegypti mosquito. Due to its great epidemiological relevance, efforts have been made by the government to promote the control of the transmission agent. The usual forms of mosquito control occur through chemical insecticides, such as organochlorines and organophosphates (Moreira et al., 2012). Due to the high environmental persistence, the tendency to accumulate in organisms, the high degree of toxicity to animals and the emergence of resistance in insects (Sucen, 2001), organochlorines have had their use reduced or even discontinued in many countries. Organophosphates have a higher acute toxicity for mammals, are chemically unstable and biodegradable, have a short persistence in soil, and need to be replaced periodically (Nascimento \& Melnyk, 2016), and have been widely used in the health area.

Given the need to develop alternative ways to combat the vector, the use of plant extracts and essential oils with larvicidal properties has shown promise because it is an easy method to obtain, low production cost and low residual effect. Cavalcanti et al. (2004) proved the larvicidal activity of nine Brazilian species against Ae. aegypti, such as Alpinia zerumbet and Hyptis suaveolens. Essential oils are complex natural mixtures that contain about 20-60 components in different concentrations (Bakkali et al., 2008), being composed predominantly of terpenic hydrocarbons and terpenoids. They are characterized by two or three main components in reasonably high concentration (20\% - 70\%) compared to other components present in trace amounts (Koul et al., 2008). Essential oils can be produced in all parts of the plant, such as in barks, stems, flowers, leaves, fruits, branches, roots, seeds (Bizzo et al., 2009), and are stored in secretory cells, cavities, channels, epidermal cells or glandular trichomes (Carréra, 2016).

The Brazilian flora is characterized by its vast biodiversity. Of a total of more than 46,000 species, 14,776 are in the Amazon Forest, 5,865 in the Caatinga, 13,566 in the Cerrado domain, 1,588 in the Pantanal biome, 2,096 in the Pampa and 20,174 in the Atlantic Forest (Guatimosim, 2020). Of these, 43\% are endemic to the national territory, placing Brazil as the country with the highest plant richness in the world (Jacques, 2016), being identified annually, on average, 250 species (Fioravanti, 2016). Despite its richness and potential, Brazilian biodiversity is still little known, and its use has been greatly neglected (Coradin et al., 2018). Therefore, it is essential to intensify the investment in research in the search for a better use of this natural heritage (Coradin et al., 2011). In this review, we sought to gather articles proving the larvicidal potential of the essential oil of botanical species verified in the national territory against Ae. aegypti. 


\section{Methodology}

This systematic review article addressed the topic: "Larvicidal properties of essential oils from plants occurring in Brazil against Ae. aegypti", seeking to answer the following question: "Is there evidence of the effectiveness of using essential oils from plants occurring in Brazil to combat Ae. aegypti? The search was conducted in the following databases: Portal de Periódicos CAPES/MEC; PubMed.gov; SciELO.org; ScienceDirect (Elsevier); and Web of Science - Core Collection (Clarivate Analytics), using the descriptors: Aedes aegypti; Brazil; Brazilian plants; essential oil; larvicidal. These were selected based on the terms suggested by the descriptor locator in Health Sciences DeCS/MeSH Finder for the theme addressed. The values of the median lethal concentration $\left(\mathrm{LC}_{50}\right)$ - the dose of the substance needed to kill $50 \%$ of the test population - were observed, as well as the larval instar (L1 to L4), botanical material collected, and exposure time.

The inclusion criteria used to select the articles were: articles on Brazilian plants (or with occurrence in Brazil) used as larvicide to combat Ae. aegypti; articles in English, Portuguese, or Spanish; full text available. The reading order for the choice of articles was title, abstract and content. The temporal inclusion criterion for the articles comprised the publication date between 2000 and 2020. We did not consider articles about seaweed used as larvicide; articles that use plant extract instead of essential oil, or the mixture of essential oils from different plants, or the association of essential oil with chemical insecticides; articles whose results did not demonstrate the efficacy of the essential oil; and review articles. The analysis and data collection were carried out by three fixed evaluators, and when there was disagreement, a fourth evaluator was recruited. This systematic review was based on the article published by Marmitt et al. (2015).

\section{Results}

The search resulted in the identification of 395 publications that, after checking eligibility following the inclusion criteria, 134 were discarded for not meeting the criteria 'full article', 'year of publication' and 'language'. After reading the sections 'title', 'abstract' and 'full article' (Figure 1), 36 papers were selected as 'articles of interest'. The main characteristics of the articles discarded in the reading stage corresponded to research conducted using seaweed, essential oil mixtures, isolated oil compounds, plant extracts, nanoemulsions, nanosuspensions and oleoresins. Following these criteria, there was disagreement among the evaluators in the selection of articles regarding the inclusion of the latter three, which was resolved through the opinion of an external evaluator, who recommended their exclusion.

Figure 1. Schematic representation of the article selection process.

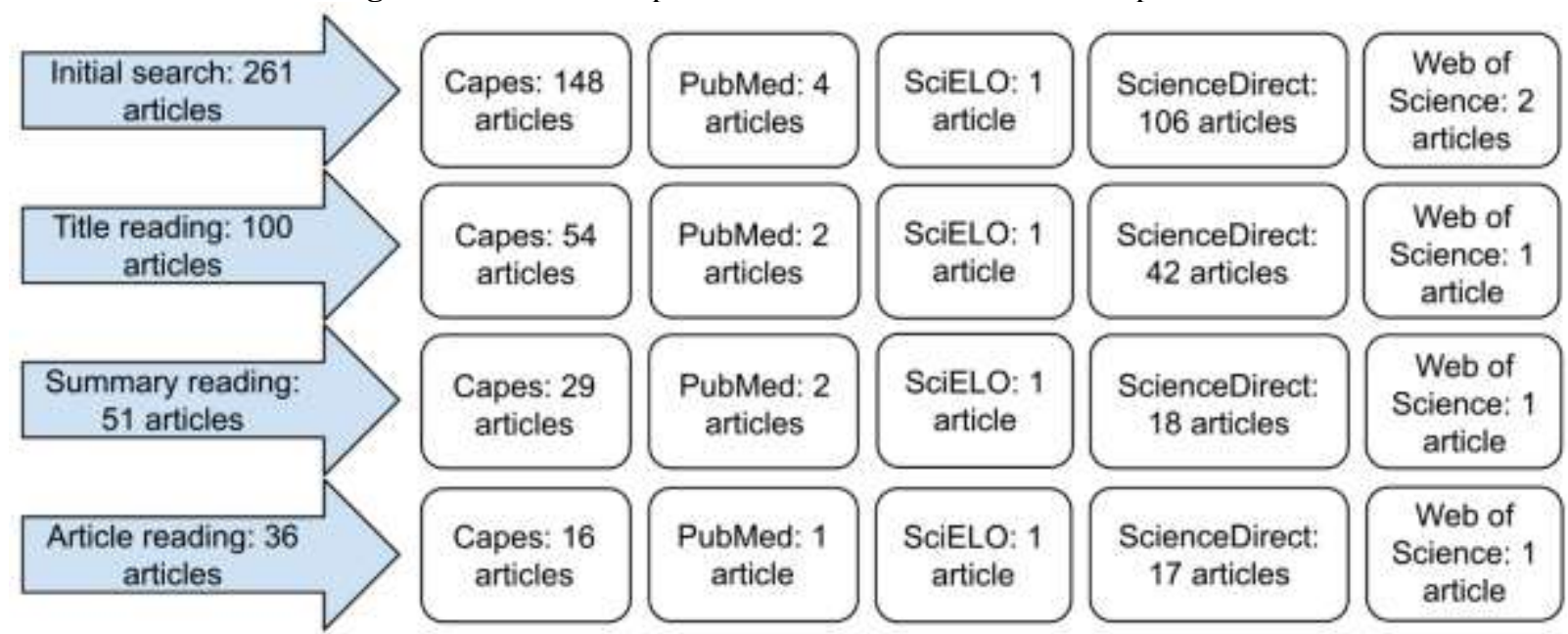

Source: Authors. 
In Figure 1, the ScienceDirect (17) and Capes (16) databases had the most articles selected, while the PubMed (1), SciELO (1), and Web of Science (1) databases had only one article selected.

The relevant information from each research was summarized in Table 1, which presents the median lethal concentration $\left(\mathrm{LC}_{50}\right)$ values obtained in the analyzed articles, highlighting the major constituents present in the chemical composition of the essential oil of each species. The lethality data were converted to the same unit of measurement, enabling comparison of their efficacy against $A e$. aegypti larvae. It was considered that $1 \mathrm{mg} / 1=1 \mu \mathrm{g} / \mathrm{mL}$ is approximately equivalent to 1 ppm.

Table 1. Median lethal concentration $\left(\mathrm{LC}_{50}\right)$ values obtained.

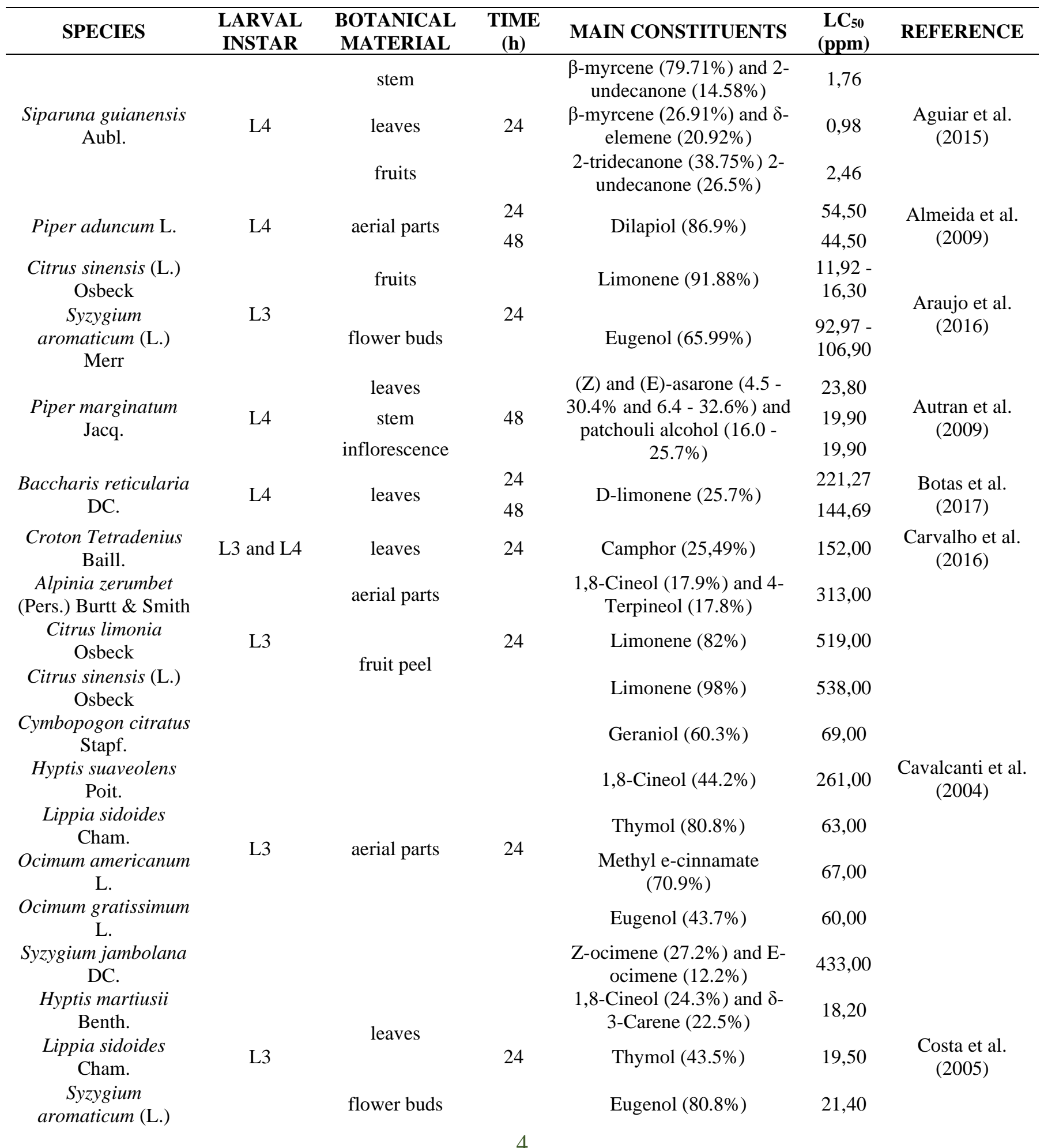




\begin{tabular}{|c|c|c|c|c|c|c|}
\hline SPECIES & $\begin{array}{l}\text { LARVAL } \\
\text { INSTAR }\end{array}$ & $\begin{array}{l}\text { BOTANICAL } \\
\text { MATERIAL }\end{array}$ & $\begin{array}{c}\text { TIME } \\
\text { (h) }\end{array}$ & MAIN CONSTITUENTS & $\begin{array}{c}\mathbf{L C}_{50} \\
(\mathbf{p p m})\end{array}$ & REFERENCE \\
\hline Merr. \& Perry & & & & & & \multirow{6}{*}{$\begin{array}{l}\text { Dias et al. } \\
\quad(2015)\end{array}$} \\
\hline $\begin{array}{c}\text { Eugenia piauhiensis } \\
\text { Vellaff. }\end{array}$ & \multirow{5}{*}{ L3 } & \multirow{5}{*}{ leaves } & \multirow{5}{*}{24} & $\begin{array}{c}\gamma \text {-elemene }(17.48 \%) \text { and E- } \\
\beta \text {-caryophyllene }(16.46 \%)\end{array}$ & 230,00 & \\
\hline $\begin{array}{l}\text { Lippia gracilis } \\
\text { Schauer. }\end{array}$ & & & & 1,8-Cineol (56.16\%) & 282,00 & \\
\hline $\begin{array}{c}\text { Myrcia erythroxylon } \\
\text { O. Berg }\end{array}$ & & & & Germacrene D (26.79\%) & $>1000$ & \\
\hline $\begin{array}{l}\text { Psidium myrsinites } \\
\text { DC. }\end{array}$ & & & & $\begin{array}{c}\text { E- } \beta \text {-Caryophyllene } \\
(26.05 \%) \text { and } \alpha \text {-humulene } \\
(23.92 \%)\end{array}$ & 292,00 & \\
\hline $\begin{array}{l}\text { Siparuna camporum } \\
\text { (Tul.) A. DC. }\end{array}$ & & & & $\gamma$-patchoulene $(28.63 \%)$ & 251,00 & \\
\hline $\begin{array}{l}\text { Citrus sinensis (L.) } \\
\text { Osbeck }\end{array}$ & L3 & fruits & 24 & R-limonene (96.3\%) & 21,50 & $\begin{array}{l}\text { Galvão et al. } \\
\quad(2015)\end{array}$ \\
\hline Tagetes minuta $\mathrm{L}$. & L3 & leaves & 24 & - & $\begin{array}{c}0,21- \\
0,25\end{array}$ & $\begin{array}{l}\text { Lima et al. } \\
\text { (2009) }\end{array}$ \\
\hline $\begin{array}{l}\text { Mentha } x \text { villosa } \\
\text { Huds. }\end{array}$ & L3 & leaves & 24 & $\begin{array}{l}\text { Piperitenone oxide } \\
\quad(70.96 \%)\end{array}$ & 45,00 & $\begin{array}{l}\text { Lima et al. } \\
\text { (2013) }\end{array}$ \\
\hline $\begin{array}{l}\text { Mesosphaerum } \\
\text { suaveolens }(\mathrm{L} .) \\
\text { Kuntze }\end{array}$ & L3 & aerial parts & 24 & $\begin{array}{l}\text { 1,8-Cineol (30,15 - } \\
\text { 64,44\%) }\end{array}$ & $\begin{array}{c}90,9- \\
135,20\end{array}$ & $\begin{array}{l}\text { Luz et al. } \\
\text { (2020) }\end{array}$ \\
\hline Thymus vulgaris $\mathrm{L}$. & L1 and L3 & - & 24 & Thymol (53.2\%) & 43,43 & $\begin{array}{l}\text { Maia et al. } \\
\text { (2019) }\end{array}$ \\
\hline $\begin{array}{l}\text { Lippia origanoides } \\
\text { Kunth. }\end{array}$ & L3 & leaves & $\begin{array}{l}24 \\
48 \\
72\end{array}$ & Carvacrol (48.31\%) & $\begin{array}{l}187,30 \\
138,60 \\
112,00\end{array}$ & $\begin{array}{l}\text { Mar et al. } \\
\text { (2018) }\end{array}$ \\
\hline Psidium guajava $\mathrm{L}$. & L4 & leaves & 24 & $\begin{array}{l}\text { E-Caryophyllene (7.6 - } \\
26.6 \%) \text { and caryophyllene } \\
\text { oxide }(3.2-16.6 \%)\end{array}$ & $\begin{array}{c}39,48- \\
64,25\end{array}$ & $\begin{array}{l}\text { Mendes et al. } \\
\quad(2017)\end{array}$ \\
\hline $\begin{array}{c}\text { Ageratum conyzoides } \\
\text { L. }\end{array}$ & \multirow{5}{*}{ L4 } & - & \multirow{5}{*}{48} & & 0,15 & \multirow{5}{*}{$\begin{array}{l}\text { Mendonça et al } \\
\text { (2005) }\end{array}$} \\
\hline $\begin{array}{c}\text { Anacardium } \\
\text { occidentale L. }\end{array}$ & & chestnut & & & 0,01 & \\
\hline $\begin{array}{l}\text { Carapa guianensis } \\
\text { Aubl. }\end{array}$ & & & & - & 0,06 & \\
\hline $\begin{array}{c}\text { Copaifera } \\
\text { langsdorffii Desf. }\end{array}$ & & - & & & 0,04 & \\
\hline $\begin{array}{c}\text { Cymbopogon } \\
\text { winterianus Jowitt. }\end{array}$ & & & & & 0,10 & \\
\hline $\begin{array}{c}\text { Piper } \\
\text { gaudichaudianum } \\
\text { Kunth. }\end{array}$ & \multirow{4}{*}{ L3 } & \multirow{4}{*}{ leaves } & \multirow{4}{*}{24} & $\begin{array}{l}\text { Viridiflorol }(27.5 \%) \text { and } \\
\text { aromadendrene }(15.55 \%)\end{array}$ & 121,00 & \multirow{4}{*}{$\begin{array}{l}\text { Morais et al. } \\
\quad(2007)\end{array}$} \\
\hline $\begin{array}{c}\text { Piper } \\
\text { hostmannianum } \\
\text { (Miq.) C. DC }\end{array}$ & & & & $\begin{array}{l}\text { Asaricin }(27.37 \%) \text { and } \\
\text { myristicin }(20.26 \%)\end{array}$ & 54,00 & \\
\hline $\begin{array}{l}\text { Piper humaytanum } \\
\text { Yunck. }\end{array}$ & & & & $\begin{array}{c}\text { Caryophyllene oxide } \\
(16.63 \%) \text { and } \beta \text {-selinene } \\
(15.77 \%)\end{array}$ & 156,00 & \\
\hline $\begin{array}{c}\text { Piper } \\
\text { permucronatum } \\
\text { Yunck. }\end{array}$ & & & & $\begin{array}{l}\text { Dilapiol }(54.7 \%) \text { and } \\
\text { myristicin }(25.61 \%)\end{array}$ & 36,00 & \\
\hline $\begin{array}{l}\text { Lippia rigida } \\
\text { Schauer. }\end{array}$ & - & leaves & - & $\begin{array}{l}\alpha \text {-humulene }(42.3 \%) \text { and } \beta \text { - } \\
\text { caryophyllene }(13.0 \%)\end{array}$ & 138,90 & $\begin{array}{l}\text { Oliveira et al. } \\
\text { (2016) }\end{array}$ \\
\hline $\begin{array}{l}\text { Anacardium humile } \\
\text { Saint Hill. }\end{array}$ & L4 & leaves & 24 & - & 20,90 & $\begin{array}{l}\text { Porto et al. } \\
\quad(2008)\end{array}$ \\
\hline $\begin{array}{c}\text { Schinus } \\
\text { terebinthifolia Raddi. }\end{array}$ & L3 & fruits and seeds & $\begin{array}{l}24 \\
48\end{array}$ & $\begin{array}{c}\delta \text {-3-carene }(55.36 \%), \alpha- \\
\text { pinene }(15.62 \%), \text { and }\end{array}$ & $\begin{array}{l}476,23 \\
419,97\end{array}$ & $\begin{array}{l}\text { Pratti et al. } \\
\quad(2015)\end{array}$ \\
\hline
\end{tabular}




\begin{tabular}{|c|c|c|c|c|c|c|}
\hline SPECIES & $\begin{array}{l}\text { LARVAL } \\
\text { INSTAR }\end{array}$ & $\begin{array}{l}\text { BOTANICAL } \\
\text { MATERIAL }\end{array}$ & $\begin{array}{l}\text { TIME } \\
\text { (h) }\end{array}$ & MAIN CONSTITUENTS & $\begin{array}{c}\mathbf{L C}_{50} \\
(\mathbf{p p m})\end{array}$ & REFERENCE \\
\hline & & & 72 & sylvesthrene (10.69\%) & 366,92 & \\
\hline Carapa guianensis & & & & & $136-$ & \\
\hline $\begin{array}{c}\text { Aublet } \\
\text { Copaifera sp. }\end{array}$ & L3 and L4 & - & 24 & - & $\begin{array}{c}141 \\
47-48\end{array}$ & $\begin{array}{l}\text { Prophiro et al. } \\
\text { (2011) }\end{array}$ \\
\hline Mentha piperita $\mathrm{L}$. & L3 & leaves & 48 & $\begin{array}{l}\text { Linalool (51.8\%) and } \\
\text { epoxyocimene (19.3\%) }\end{array}$ & 367,60 & $\begin{array}{l}\text { Ramos et al. } \\
\text { (2017) }\end{array}$ \\
\hline $\begin{array}{l}\text { Helicteres velutina } \\
\text { K. Schum. }\end{array}$ & L4 & roots, stems, & 48 & - & 138,90 & Santos et al. \\
\hline Scoparia dulcis $\mathrm{L}$. & & & & & 83,43 & \\
\hline $\begin{array}{l}\text { Alpinia purpurata } \\
\text { (Viell.) K. Schum. }\end{array}$ & & & & $\begin{array}{c}\alpha \text {-pinene }(13.86 \%), \beta- \\
\text { pinene }(26.56 \%) \text { and } \beta \text { - }\end{array}$ & 71,50 & \\
\hline $\begin{array}{c}\text { (Pink variant) } \\
\text { Alpinia purpurata }\end{array}$ & L4 & flowers & 24 e 48 & & & $\begin{array}{l}\text { Santos et al. } \\
\text { (2012) }\end{array}$ \\
\hline $\begin{array}{l}\text { (Viell.) K. Schum. } \\
\text { (Red variant) }\end{array}$ & & & & $\begin{array}{c}(13.93 \%) \text { and } \beta- \\
\text { caryophyllene }(18.26 \%)\end{array}$ & 80,70 & \\
\hline $\begin{array}{l}\text { Syagrus coronata } \\
\text { (Mart.) Becc. }\end{array}$ & L4 & seeds & 48 & $\begin{array}{c}\text { Octanoic acid }(40.55 \%) \text { and } \\
\text { dodecanoic acid }(40.48 \%)\end{array}$ & 21,07 & $\begin{array}{l}\text { Santos et al. } \\
\quad(2017)\end{array}$ \\
\hline $\begin{array}{l}\text { Pogostemon cablin } \\
\text { (Blanco) Benth. }\end{array}$ & L3 & leaves & 24 & $\begin{array}{l}\text { Patchouli Alcohol } \\
\text { (33.25\%) and Seychelene } \\
(6.12 \%)\end{array}$ & 28,43 & $\begin{array}{l}\text { Santos et al. } \\
\text { (2019) }\end{array}$ \\
\hline $\begin{array}{l}\text { Syzygium } \\
\text { aromaticum }(\mathrm{L} .) \\
\text { Merr. \& Perry }\end{array}$ & L3 and L4 & flower buds & 24 & Eugenol $(71.92 \%)$ & 40,74 & $\begin{array}{l}\text { Santos et al. } \\
\quad(2020)\end{array}$ \\
\hline $\begin{array}{l}\text { Hyptis fruticosa } \\
\text { Salzm. }\end{array}$ & & & & $\begin{array}{l}\text { 1,8-Cineol }(15.79 \%) \text { and } \\
\text { spatulenol }(10.23 \%)\end{array}$ & 502,00 & \\
\hline Hyptis pectinata Poit. & L3 and L4 & leaves & 24 & $\begin{array}{c}\beta \text {-Caryophyllene }(40.90 \%) \\
\text { and caryophyllene oxide } \\
(38.05 \%)\end{array}$ & 366,00 & $\begin{array}{l}\text { Silva et al. } \\
\quad(2007)\end{array}$ \\
\hline $\begin{array}{l}\text { Lippia gracilis } \\
\text { Schauer. }\end{array}$ & & & & Carvacrol $(44.43 \%)$ & 98,00 & \\
\hline $\begin{array}{c}\text { Schinus } \\
\text { terebinthifolia Raddi. }\end{array}$ & L3 & fruits & 24 & $\begin{array}{c}\delta \text {-3-carene }(55.43 \%) \text { and } \alpha- \\
\text { pinene }(16.25 \%)\end{array}$ & $\begin{array}{c}172,44 \\
- \\
344,88\end{array}$ & $\begin{array}{l}\text { Silva et al. } \\
\text { (2010) }\end{array}$ \\
\hline $\begin{array}{c}\text { Commiphora } \\
\text { leptophloeos Leat. }\end{array}$ & L4 & leaves & 48 & $\begin{array}{c}\alpha \text {-Felandrene }(26.3 \%),(\mathrm{E})- \\
\text { caryophyllene }(18.0 \%) \text { and } \\
\beta \text {-Felandrene }(12.9 \%)\end{array}$ & 99,40 & $\begin{array}{l}\text { Silva et al. } \\
\text { (2015) }\end{array}$ \\
\hline $\begin{array}{l}\text { Piper corcovadensis } \\
\text { (Miq.) C. DC }\end{array}$ & L4 & leaves & 24 e 48 & $\begin{array}{c}\text { 1-Butyl-3,4- } \\
\text { methylenedioxy benzene } \\
(30.62 \%)\end{array}$ & 30,52 & $\begin{array}{l}\text { Silva et al. } \\
\quad(2016)\end{array}$ \\
\hline $\begin{array}{l}\text { Vitex gardneriana } \\
\text { Schauer. }\end{array}$ & L3 & leaves & 24 & $\begin{array}{c}\text { 6,9-guaiadiene (10.13 - } \\
30.15 \%) \text { and calamenene } \\
\text { <cis> }(21.29-35.62 \%)\end{array}$ & $\begin{array}{c}28,0- \\
84,3\end{array}$ & $\begin{array}{l}\text { Silva et al. } \\
\text { (2019) }\end{array}$ \\
\hline $\begin{array}{l}\text { Bauhinia cheilantha } \\
\text { (Bong.) Steud. }\end{array}$ & L3 & leaves & 24 & $\begin{array}{c}\text { (E)-caryophyllene } \\
(21.65 \%) \text { and } \alpha \text {-pinene } \\
(11.75 \%)\end{array}$ & 40,84 & $\begin{array}{l}\text { Silva et al. } \\
\text { (2020) }\end{array}$ \\
\hline $\begin{array}{c}\text { Copaifera multijuga } \\
\text { Hayne. }\end{array}$ & L3 and L4 & $\begin{array}{l}\text { oil-resin, bark, } \\
\text { and leaves }\end{array}$ & 24 e 48 & $\begin{array}{l}\beta \text {-Caryophyllene }(57.1 \%) \\
\text { and } \alpha \text {-humulene }(10.2 \%)\end{array}$ & 18,00 & $\begin{array}{l}\text { Trindade et al. } \\
\text { (2013) }\end{array}$ \\
\hline $\begin{array}{c}\text { Illicium verum Hook. } \\
\text { f. }\end{array}$ & & fruits & & (E)-anethole (90.1\%) & 39,80 & \\
\hline $\begin{array}{c}\text { Myristica fragrans } \\
\text { Houtt. }\end{array}$ & L3 & seeds & 24 & $\begin{array}{c}\text { Sabinene }(52.1 \%) \alpha \text {-pinene } \\
(12.8 \%)\end{array}$ & 28,20 & $\begin{array}{l}\text { Voris et al. } \\
\text { (2018) }\end{array}$ \\
\hline $\begin{array}{l}\text { Pimenta dioica (L.) } \\
\text { Merr. }\end{array}$ & & fruits & & $\begin{array}{c}\text { Methyl eugenol }(55.0 \%) \\
\text { and eugenol }(36.3 \%)\end{array}$ & 104,40 & \\
\hline
\end{tabular}


In Table 1, the components 1,8-cyenol (9.23\%), limonene (7.69\%) and eugenol (7.69\%) had the highest frequency of appearance as major constituents of the essential oil. The species Ageratum conyzoides L., Anacardium occidentale L., Carapa guianensis Aubl., Copaifera langsdorffii Desf., Cymbopogon winterianus Jowitt., Siparuna guianensis Aubl. and Tagetes minuta $\mathrm{L}$. showed the lowest $\mathrm{LC}_{50}$ values $(0.01-2.46 \mathrm{ppm})$, while the species Myrcia erythroxylon O. Berg presented the highest $\mathrm{LC}_{50}$ value $\left(\mathrm{LC}_{50}>1000\right.$ ppm). The trials used mainly L3 (47.22\%), L4 (33.33\%) and L3/L4 (13.89\%) instar larvae.

\section{Discussion}

Terpenes represent the largest class of secondary metabolites, with recognized antimicrobial activity (De Martino et al., 2015; Lutfi \& Roque, 2014). Chemically, they present a carbon-carbon double bond being characterized as an unsaturated hydrocarbon (McMurry, 2011). On the other hand, if a terpene contains oxygen, it is called a terpenoid, and may have different chemical functions, including acids, alcohols, aldehydes, ketones, ethers, phenols or terpenic epoxides (Felipe et al., 2016). Terpenes/terpenoids are basically structured in isoprene $\left(\mathrm{C}_{5} \mathrm{H}_{8}\right)$ blocks, usually linked together in the "head-to-tail" order (bond 1-4) (Loomis et al., 2014; Eschenmoser et al.,2005), except for "irregular terpenes" ("tail-to-tail" bond (bond 4-4)) and cyclic terpenes ("cross-links"). Monoterpenes (two isoprene blocks) are the main constituents of volatile oils, acting in attracting pollinators, while sesquiterpenes (three isoprene blocks) protect plants against fungi and bacteria (Gershenzon et al., 2007). Thus, the relationship between the structural form of the molecules and their biological properties becomes evident (Strub et al., 2014).

The analysis of the chemical composition of the essential oils presented in Table 1 shows the majority presence of the secondary metabolites monoterpenes, sesquiterpenes and phenylpropenes, such as limonene and 1,8-cineole, (E) and ( $\beta$ )caryophyllene, and eugenol, respectively. The terpenes 1,8-cyenol (9.23\%) and limonene (7.69\%) and the phenylpropene eugenol $(7.69 \%)$ had the highest frequency of appearance in the papers as major constituents of the essential oil. Limonene is the main constituent of the essential oil of the peels of citrus fruits (genus Citrus), such as lemons (C. limonia Osbeck) and oranges (C. sinensis (L.) Osbeck) and is responsible for the characteristic odor that these fruits present. The 1,8-cineol or eucalyptol is found in the essential oil of the leaves of botanical species of the genus Eucalyptus, being also reported to occur in plants of the genus Hyptis, as in H. fruticosa Salzm. (Silva et al., 2007), H. martiusii Benth. (Costa et al., 2005) and H. suaveolens Poit. (Cavalcanti et al., 2004). The caryophyllene is present in the composition of many essential oils used as spices, especially in clove, rosemary, and black pepper. Eugenol is the predominant component of the essential oil of clove (Syzygium aromaticum (L.) Merr. \& Perry), as reported by Araujo et al. (2016), Costa et al. (2005), and Santos et al. (2020).

To classify the larvicidal potential of essential oils, the literature provides different criteria, and there are no standardized median lethal concentration values for determining the efficiency of the analyzed substances. According to Kiran et al. (2016), the larvicidal effect is considered significant in essential oils with $\mathrm{LC}_{50}$ less than 100 ppm under $24 \mathrm{~h}$ of exposure. Another methodology is proposed by Komalamisra et al. (2005), according to which substances that present LC 50 less than 50 ppm are considered strongly active, $\mathrm{LC}_{50}$ between 50 and 100 ppm, moderately active, and LC 50 between 100 and 750 ppm, effective, while those with $\mathrm{LC}_{50}$ values higher than $750 \mathrm{ppm}$ are considered inactive, under $48 \mathrm{~h}$ of exposure. Table 2 shows the classification of the studied plants adopting the second specification presented. For items that present different larvicidal potentials for the same plant, depending on the botanical material used, place of larval collection, and time of exposure to the essential oil, the lethality considered corresponds to the arithmetic mean of the $\mathrm{LC}_{50}$ values. 
Table 2. Classification of larvicidal potential according to Komalamisra et al. (2005).

\begin{tabular}{ccc}
\hline $\mathbf{L C}_{\mathbf{5 0}}(\mathbf{p p m})$ & Classification & Species \\
\hline$<50$ & highly active & 27 \\
$50-100$ & moderately active & 13 \\
$100-750$ & effective & 24 \\
$>750$ & inactive & 1 \\
\hline
\end{tabular}

Source: Authors.

In Table 2, of the 65 plants described, 27 are classified as strongly active (41.54\%), 13 are moderately active (20.00\%), 24 are effective (36.92\%), and only 1 is inactive (1.54\%).

The species Carapa guianensis Aublet, Citrus sinensis (L.) Osbeck, Lippia gracilis Schauer., Lippia sidoides Cham., Schinus terebinthifolia Raddi. and Syzygium aromaticum (L.) Merr. have been studied in more than one article, being assigned different classifications according to the larvicidal potential obtained. For example, Araujo et al. (2016), Costa et al. (2005) and Santos et al. (2020) analyzed the larvicidal activity of the essential oil of S. aromaticum floral buds, against larvae (L3, L3 and L3/L4, respectively) of Ae. aegypti, during a 24h exposure period. The analysis of the chemical composition of the essential oil identified eugenol as the main constituent $(65.99 \%, 80.80 \%$ and $71.92 \%$, respectively). As for larvicidal activity, $S$. aromaticum was classified as strongly active considering the articles by Costa et al. (2005) and Santos et al. (2020), while it was shown to be moderately active/effective considering the article by Araujo et al. (2016) ( $\mathrm{LC}_{50}$ of 40.74, 21.40 and 92.97 106.90 ppm, respectively). A possible explanation for the lower lethality of the essential oil in the study by Araujo et al. (2016) may be attributed to the lower percentage of eugenol in the chemical composition of the oil, as well as the use of resistant populations of Ae. aegypti in the experiment.

The species that stood out as promising plants for having greater larvicidal potential were: Anacardium occidentale $\mathrm{L}$. (0.01 ppm), Copaifera langsdorffii Desf. (0.04 ppm), Carapa guianensis Aubl. (0.06 ppm), Cymbopogon winterianus Jowitt. $(0.10 \mathrm{ppm})$ and Ageratum conyzoides L. (0.15 ppm), in the study by Mendonça et al. (2005); Tagetes minuta L. (0.21 - 0.25 ppm), in the study by Lima et al. (2009); and Siparuna guianensis Aubl. (1.76, 0.98 and 2.46 ppm), in the study by Aguiar et al. (2015).

Of the species mentioned above, the identification of the chemical composition of the essential oil was performed only for S. guianensis. The main components were dependent on the botanical material used for essential oil extraction, being $\beta$-myrcene (79.71\%) for stems, $\beta$-myrcene $(26.91 \%)$ for leaves, and 2-tridecanone (38.75\%) for fruits. This fact was not observed in the study of Autran et al. (2009), where the essential oil of Piper marginatum Jacq. showed the same composition ((Z) and (E)-asarone and patchouli alcohol) when extracted from leaves, stem, and inflorescences, varying only the percentage with respect to the total composition. The chemical composition of volatile oils varies between parts of the same plant and, when extracted from the same organ of the same plant species, can vary significantly according to age and stage of development, season and time of collection, weather and soil conditions, and their properties depend on the extraction technique used (Burt, 2004; Morais, 2009).

The only species that showed inactivity against Ae. aegypti larvae was Myrcia erythroxylon $\mathrm{O}$. Berg with $\mathrm{LC}_{50}>1000$ ppm, reported by Dias et al. (2015). The majority constituents identified in the essential oil of the plant were the sesquiterpenes germacrene $\mathrm{D}(26.79 \%)$, bicyclogermacrene (13.26\%) and (E)- $\beta$-caryophyllene (10.55\%). In the articles analyzed, germacrene $\mathrm{D}$ and bicyclogermacrene did not appear as majority constituents for any of the other species, which may be an indication of the inefficacy of these compounds as larvicide against Ae. aegypti. The (E)- $\beta$-caryophyllene was identified in the chemical composition of the species Eugenia piauhiensis Vellaff. and Psidium myrsinites DC. (E)-caryophyllene was found in Psidium guajava L., Commiphora leptophloeos Leat and Bauhinia cheilantha (Bong.) Steud., while $\beta$-caryophyllene was detected in 
Lippia rigida Schauer., Alpinia purpurata (Viell.) K. Schum., Hyptis pectinata Poit. and Copaifera multijuga Hayne. The approach of a possible explanation for the high $\mathrm{LC}_{50}$ value obtained was not presented by the authors. Also, no new research regarding the larvicidal activity of $M$. erythroxylon essential oil was found in the literature.

Among the species studied, the presence of species endemic to Brazil stands out, such as Baccharis reticularia DC, Croton tetradenius Baill., Helicteres velutina K. Schum., Hyptis fruticosa Salzm., Hyptis martiusii Benth., Lippia gracilis Schauer, Lippia sidoides Cham., Psidium myrsinites DC., Syagrus coronata (Mart.) Becc. and Vitex gardneriana Schauer. Note that such species correspond to a small percentage $(17.86 \%)$ in relation to the total number of species analyzed, which shows the lack of knowledge of the existing native flora, although Brazil is a country of great biodiversity.

The occurrence of species exclusive to the Northeast region of Brazil and the Caatinga biome is also observed. Croton tetradenius Baill. is endemic to the Caatinga biome and is frequently found in most states of the Northeast region of Brazil (Carvalho et al., 2016). Lippia gracilis Schauer is endemic to Northeast Brazil and is widely distributed in the Caatinga (Gomes et al., 2011). Vitex gardneriana Schauer is a native and endemic species of Brazil, having its distribution restricted only to the Northeast region (Soares, 2017).

\section{Conclusion}

Unlike chemical insecticides, which are harmful to the environment and, when unstable, require periodic application to the soil, essential oils are an eco-friendly and economically viable alternative in combating arboviruses transmitted by Ae. aegypti. Brazil has a vast natural wealth, with about 46 thousand plant species in the most diverse biomes, $43 \%$ of which are endemic to the national territory. The essential oils from different botanical species of Brazilian flora proved to be efficient in fighting the larvae of the Ae. aegypti mosquito. Of the 65 plants evidenced in the research, the species Anacardium occidentalis L. (0.01 ppm), Copaifera langsdorffi Desf. (0.04 ppm) and Carapa guianensis Aubl. (0.06 ppm) were the most effective among the 27 strongly active species, besides the occurrence of 13 moderately active species, 24 effective, and only one inactive, according to the classification proposed by Komalamisra et al. (2005). Thus, it was proven the ability to use plants grown in the national territory as an alternative in combating Ae. aegypti. Therefore, studies on the essential oils of Brazilian plants are of great relevance, not only to combat arboviruses, but also due to their potential for medicinal applications, showing other relevant properties.

As suggestions for future work, we recommend the analysis of the larvicidal activity of essential oils from Brazilian plants against Ae. aegypti with different approaches, prioritizing the species that occur exclusively in the Northeast region and the Caatinga biome, to explore the vast biodiversity and the enormous potential existing in the native flora of this region.

\section{Acknowledgments}

The authors are grateful to the Coordenação de Aperfeiçoamento de Pessoal de Nível Superior - Brazil (CAPES) for the financial support (Funding Code 001).

\section{References}

Aguiar, R. W. S., Santos, S. F., Morgado, F. S., Ascencio, S. D., Lopes, M. M., Viana, K. F. et al. (2015). Insecticidal and repellent activity of Siparuna guianensis Aubl. (Negramina) against Aedes aegypti and Culex quinquefasciatus. Plos One, 10(2), 1-14. doi:10.1371/journal.pone.0116765

Almeida, R. R. P., Souto, R. N. P., Bastos, C. N., Silva, M. H. L. \& Maia, J. G. S. (2009). Chemical variation in Piper aduncum and biological properties of its dillapiole-rich essential oil. Chem. Biodivers., 6(9), 1427-34. doi:10.1002/cbdv.200800212

Araujo, A. F. O., Ribeiro-Paes, J. T., Deus, J. T., Cavalcanti, S. C. H., Nunes, R. S., Alves, P. B. et al. (2016). Larvicidal activity of Syzygium aromaticum (L.) Merr and Citrus sinensis (L.) Osbeck essential oils and their antagonistic effects with temephos in resistant populations of Aedes aegypti. Meml. Inst. Oswaldo Cruz, 111(7), 443-9. doi:10.1590/0074-02760160075 
Autran, E. S., Neves, I. A., Silva, C. S. B., Santos, G. K. N., Câmara, C. A. G. \& Navarro, D. M. A. F. (2009). Chemical composition, oviposition deterrent and larvicidal activities against Aedes aegypti of essential oils from Piper marginatum Jacq. (Piperaceae). Bioresour. Technol., 100(7), 2284-8. doi:10.1016/j.biortech.2008.10.055

Bakkali, F., Averbeck, S., Averbeck, D. \& Idaomar, M. (2008). Biological effects of essential oils: a review. Food Chem. Toxicol., 46(2), 446-75. doi:10.1016/j.fct.2007.09.106

Bizzo, H. R., Hovell, A. M. C. \& Rezende, C. M. (2009). Brazilian essential oils: general view, developments and perspectives. Quím. Nova, 32(3), 588-94. doi:10.1590/S0100-40422009000300005

Botas, G. S., Cruz, R. A. S., Almeida, F. B., Duarte, J. L., Araújo, R. S., Souto, R. N. et al. (2017). Baccharis reticularia DC. and limonene nanoemulsions: promising larvicidal agents for Aedes aegypti (Diptera: Culicidae) Control. Molecules, 22(11), 1-14. doi:10.3390/molecules22111990

Burt, S. (2004). Essential oils: their antibacterial properties and potential applications in foods - a review. Int. J. Food Microbiol., 94(3), 223-53. doi:10.1016/j.ijfoodmicro.2004.03.022

Carréra, J. C. (2016). Estruturas secretoras e rendimento de óleo essencial de Croton sacaquinha Croizat. e dois morfotipos de Croton cajucara Benth. (Euphorbiaceae). Graduation work, Univ. Estado Pará, Belém - PA, Brazil. https://ainfo.cnptia.embrapa.br/digital/bitstream/item/175258/1/ESTRUTURASSECRETORAS.pdf

Carvalho, K. S., Cunha e Silva, S. L., Souza, I. A., Gualberto, S. A., Cruz, R. C. D., Santos, F. R. et al. (2016). Toxicological evaluation of essential oil from the leaves of Croton tetradenius (Euphorbiaceae) on Aedes aegypti and Mus mus musculus. Parasitol. Res., 115(9), 3441-8. doi:10.1007/s00436-016-5106-2

Cavalcanti, E. S. B., Morais, S. M., Lima, M. A. A. \& Santana, E. W. P. (2004). Larvicidal activity of essential oils from Brazilian plants against Aedes aegypti L. Meml. Inst. Oswaldo Cruz, 99(5), 541-4. doi:10.1590/S0074-02762004000500015

Coradin, L., Camillo, J. \& Pareyn, F. G. C. (2018). Espécies nativas da flora brasileira de valor econômico atual ou potencial: plantas para o futuro: região Nordeste. https://ainfo.cnptia.embrapa.br/digital/bitstream/item/189688/1/Livro-Nordeste-1-2018.pdf

Coradin, L., Siminski, A. \& Reis, A. (2011). Espécies nativas da flora brasileira de valor econômico atual ou potencial: plantas para o futuro - região Sul. Brasília: Minist. Environ. https://www.gov.br/mma/pt-br/assuntos/biodiversidade/fauna-e-flora/Regiao_Sul.pdf

Costa, J. G. M., Rodrigues, F. F. G., Angélico, E. C., Silva, M. R., Mota, M. L., Santos, N. K. A. et al. (2005). Chemical-biological study of the essential oils of Hyptis martiusii, Lippia sidoides and Syzigium aromaticum against larvae of Aedes aegypti and Culex quinquefasciatus. Rev. Bras. Farmacogn., 15(4), 3049. doi:10.1590/S0102-695X2005000400008

De Martino, L., Nazzaro, F., Mancini, E. \& De Feo, V. (2014). In: Preedy VR, Watson RR. Essential oils from Mediterranean aromatic plants. The Mediterranean diet: an evidence-based approach. Elsevier, 1(58), 649-61. doi:10.1016/B978-0-12-407849-9.00058-0

Dias, C. N., Alves, L. P. L., Rodrigues, K. A. F., Brito, M. C. A., Rosa, C. S. \& Amaral, F. M. M. (2015). Chemical composition and larvicidal activity of essential oils extracted from Brazilian legal Amazon plants against Aedes aegypti L. (Diptera: Culicidae). Hindawi, 2015(1), 1-8. doi:10.1155/2015/490765

Eschenmoser, A. \& Arigoni, D. (2005). Revisited after 50 years: the "stereochemical interpretation of the biogenetic isoprene rule for the triterpenes." Helv. Chim. Acta, 88(12), 3011-50. doi:10.1002/hlca.200590245

Felipe, L. O. \& Bicas, J. L. (2017). Terpenos, aromas e a química dos compostos naturais. Quím. Nova na Esc., 39(2), 120-30. doi:10.21577/01048899.20160068

Fioravanti, C. (2016). A maior diversidade de plantas do mundo. https://revistapesquisa.fapesp.br/a-maior-diversidade-de-plantas-do-mundo/

Galvão, J. G., Silva, V. F., Ferreira, S. G., França, F. R. M., Santos, D. A., Freitas, L. S. et al. (2015). $\beta$-cyclodextrin inclusion complexes containing Citrus Sinensis (L.) Osbeck essential oil: an alternative to control Aedes Aegypti larvae. Thermochim. Acta, 608(1), 14-9. doi:10.1016/j.tca.2015.04.001

Gershenzon, J. \& Dudareva, N. (2007). The function of terpene natural products in the natural world. Nat. Chem. Biol., 3(1), 408-14. doi:10.1038/nchembio. 2007.5

Gomes, S. V. F., Nogueira, P. C. L. \& Moraes, V. R. S. (2011). Aspectos químicos e biológicos do gênero Lippia enfatizando Lippia gracilis Schauer. Eclect. Chem., 36(1), 64-77. doi:10.1590/S0100-46702011000100005

Guatimosim, P. (2020). Projeto Flora do Brasil 2020 lança vídeo sobre espécies vegetais do país. http://www.faperj.br/?id=3993.2.3

Jacques, L. (2016). A maior diversidade de plantas do mundo. https://nossofuturoroubado.com.br/maior-diversidade-de-plantas-do-mundo/

Kiran, S. R., Bhavani, K., Devi, P. S., Rao, B. R. R. \& Reddy, K. J. (2006). Composition and larvicidal activity of leaves and stem essential oils of Chloroxylon swietenia DC against Aedes aegypti and Anopheles stephensi. Bioresour. Technol., 97(18), 2481-4. doi:10.1016/j.biortech.2005.10.003

Komalamisra, N., Trongtokit, Y., Rongsriyam, Y. \& Apiwathnasorn, C. (2005). Screening for larvicidal activity in some Thai plants against four mosquito vector species. Southeast Asian J. Trop. Med. Public Health, 36(6), 1412-22. doi:10.1016/j.actatropica.2019.01.019

Koul, O., Suresh, W. \& Dhaliwal, G. S. (2008). Essential oils as green pesticides: potential and constraints. Biopestic. Int., 4(1), 63-84. https://www.docdeveloppement-durable.org/file/Culture/Arbres-

Fruitiers/FICHES_ARBRES/Bael/Essential\%20Oils\%20as\%20Green\%20Pesticides_Potential\%20and\%20Constraints.pdf

Lima, T. C., Silva, T. K. M., Silva, F. L., Barbosa-Filho, J. M., Marques, M. O. M., Santos, R. L. C. et al. (2013). Larvicidal activity of Mentha x villosa Hudson essential oil, rotundifolone and derivatives. Chemosphere, 104(1), 37-43. doi:10.1016/j.chemosphere.2013.10.035 
Lima, W. P., Chiaravalloti Neto, F., Macoris, M. L. G., Zuccari, D. A. P. C. \& Dibo, M. R. (2009). Establishment of the feeding methodology of Aedes aegypti (Diptera-Culicidae) in Swiss mice and evaluation of the toxicity and residual effect of essential oil from Tagetes minuta L (Asteraceae), in populations of Aedes aegypti. Rev. Soc. Bras. Med. Trop., 42(6), 638-41. doi:10.1590/S0037-86822009000600005

Loomis, W. D. \& Croteau, R. (2014). In: Stumpf, P. K. Biochemistry of terpenoids. Lipids: structure and function: the biochemistry of plants. Elsevier, 4(13), 364-410. https://www.elsevier.com/books/lipids-structure-and-function/stumpf/978-0-12-675404-9

Lutfi, M. \& Roque, N. F. (2014). Histórias de Eugênias. Quím. Nova na Esc., 36(4), 252-60. doi:10.5935/0104-8899.20140030

Luz, T. R. S. A., Leite, J. A. C., Mesquita, L. S. S., Bezerra, S. A., Silveira, D. P. B., Mesquita, J. W. C. et al. (2020). Seasonal variation in the chemical composition and biological activity of the essential oil of Mesosphaerum suaveolens (L.) Kuntze. Ind. Crops Prod., 153(1), 1-8. doi:10.1016/j.indcrop.2020.112600

Maia, J. D., Corte, R. L., Martinez, J., Ubbink, J. \& Prata, A. S. (2019). Improved activity of thyme essential oil (Thymus vulgaris) against Aedes aegypti larvae using a biodegradable controlled release system. Ind. Crops Prod., 136(1), 110-20. doi:10.1016/j.indcrop.2019.03.040

Mar, J. M., Silva, L. S., Azevedo, S. G., França, L. P., Goes, A. F. F., Santos, A. L. et al. (2018). Lippia origanoides essential oil: an efficient alternative to control Aedes aegypti, Tetranychus urticae and Cerataphis lataniae. Ind. Crops Prod., 111(1), 292-7. doi:10.1016/j.indcrop.2017.10.033

Marmitt, D. J., Rempel, C., Goettert, M. I. \& Silva, A. C. (2015). Plants with potential antibacterial of national list medical plants of health system only interest: systematic review. Rev. Saúde Pública, 8(2), 135-51. https://docs.bvsalud.org/biblioref/2020/11/1129299/plantas-com-potencial-antibacteriano-darelacao-nacional-de-pl_gy9BcVq.pdf

McMurry, J. (2011). Química orgânica - combo. São Paulo, Brazil: Cengage Learn.

Mendes, L. A., Martins, G. F., Valbon, W. R., Souza, T. S., Menini, L., Ferreira, A. et al. (2017). Larvicidal effect of essential oils from Brazilian cultivars of guava on Aedes aegypti L. Ind. Crops Prod., 108(1), 684-9. doi:10.1016/j.indcrop.2017.07.034

Mendonça, F. A. C., Silva, K. F. S., Santos, K. K., Ribeiro Júnior, K. A. L. \& Sant'ana, A. E. G. (2005). Activities of some Brazilian plants against larvae of the mosquito Aedes aegypti. Phytotherapy, 76(7-8), 629-36. doi:10.1016/j.fitote.2005.06.013

Morais, L. A. S. (2009). Influência dos fatores abióticos na composição química dos óleos essenciais. Hortic. Bras., 27(2), 4050-63. https://ainfo.cnptia.embrapa.br/digital/bitstream/item/143457/1/2009AA-051.pdf

Morais, S. M., Facundo, V. A., Bertini, L. M., Cavalcanti, E. S. B., Anjos Júnior, J. F., Ferreira, S. A. et al. (2007). Chemical composition and larvicidal activity of essential oils from Piper species. Biochem. Syst. Ecol., 35(10), 670-5. doi:10.1016/j.bse.2007.05.002

Moreira, M. F., Mansur, J. F. \& Figueira-Mansur, J. (2012). Resistência e inseticidas: estratégias, desafios e perspectivas no controle de insetos. Natl. Inst. Sci. Technol. Mol. Entomol. http://www.inctem.bioqmed.ufrj.br/images/documentos/biblioteca/Capitulo_15_Resistencia_a_Inseticidas__Estrategias_Desafios_e_Perspectivas_no_Controle_de_Insetos.pdf

Nascimento, L. \& Melnyk, A. (2016). A química dos pesticidas no meio ambiente e na saúde. Rev. Mangaio Acad., 1(1) 54-61. https://aedmoodle.ufpa.br/pluginfile.php/416613/mod_resource/content/1/A\%20qu\%C3\%ADmica\%20dos\%20pesticidas\%20no\%20meio.pdf

Oliveira, F. C., Mafezoli, J., Barbosa, F. G., Santiago, G. M. P., Camelo, A. L. M. \& Guedes, M. L. S. (2016). Chemical composition and biological activities of the essential oil from leaves of Lippia rigida. Chem. Nat. Compd., 52(6), 1121-2. doi:10.1007/s10600-016-1881-3

Porto, K. R. A., Roel, A. R., Silva, M. M., Coelho, R. M., Scheleder, E. J. D. \& Jeller, A. H. (2008). Larvicidal activity of Anacardium humile Saint Hill oil on Aedes aegypti (Linnaeus, 1762) (Diptera, Culicidae). Rev. Soc. Bras. Med. Trop., 6(41), 586-9. doi:10.1590/S0037-86822008000600008

Pratti, D. L. A., Ramos, A. C., Scherer, R., Cruz, Z. M. A. \& Silva, A. G. (2015). Mechanistic basis for morphological damage induced by essential oil from Brazilian pepper tree, Schinus terebinthifolia, on larvae of Stegomyia aegypti, the dengue vector. Parasites \& Vectors, 8(1), 1-10. doi:10.1186/s13071-0150746-0

Prophiro, J. S., Silva, M. A. N., Kanis, L. A., Rocha, L. C. B. P., Duque-Luna, J. E. \& Silva, O. S. (2012). First report on susceptibility of wild Aedes aegypti (Diptera: Culicidae) using Carapa guianensis (Meliaceae) and Copaifera sp. (Leguminosae). Parasitol. Res., 110(2), 699-705. doi:10.1007/s00436-011-25457

Ramos, R. S., Rodrigues, A. B. L., Farias, A. L. F., Simões, R. C., Pinheiro, M. T., Ferreira, R. M. A. et al. (2017). Chemical composition and in vitro antioxidant, cytotoxic, antimicrobial, and larvicidal activities of the essential oil of Mentha piperita L. (Lamiaceae). Hindawi, 2017(1), 1-8. doi: $10.1155 / 2017 / 4927214$

Santos, A. J., Pina, L. T. S., Galvão, J. G., Trindade, G. G. G., Nunes, R. K. V., Santos, J. S. et al. (2020). Clay/PVP nanocomposites enriched with Syzygium aromaticum essential oil as a safe formulation against Aedes aegypti larvae. Appl. Clay Sci., 185(1), 1-7. doi:10.1016/j.clay.2019.105394

Santos, E. A., Carvalho, C. M., Costa, A. L. S., Conceição, A. S., Moura, F. B. P. \& Santana, A. E. G. (2011). Bioactivity evaluation of plant extracts used in indigenous medicine against the Snail, Biomphalaria glabrata, and the larvae of Aedes aegypti: evidence-based complementary and alternative medicine. Hindawi, 2012(1), 1-9. doi:10.1155/2012/846583

Santos, G. K. N., Dutra, K. A., Barros, R. A., Câmara, C. A. G., Lira, D. D., Gusmão, N. B. et al. (2012). Essential oils from Alpinia purpurata (Zingiberaceae): chemical composition, oviposition deterrence, larvicidal and antibacterial activity. Ind. Crops Prod., 40(1), 254-60. doi:10.1016/j.indcrop.2012.03.020

Santos, L. L., Brandão, L. B., Martins, R. L., Rabelo, E. M., Rodrigues, A. B. L., Araújo, C. M. C. V. et al. (2019). Evaluation of the larvicidal potential of the essential oil Pogostemon cablin (Blanco) Benth in the control of Aedes aegypti. Pharmaceuticals, 12(2), 1-13. doi:10.3390/ph12020053 
Santos, L. M. M., Nascimento, J. S., Santos, M. A. G., Marriel, N. B., Bezerra-Silva, P. C., Rocha, S. K. L. et al. (2017). Fatty acid-rich volatile oil from Syagrus coronata seeds has larvicidal and oviposition-deterrent activities against Aedes aegypti. Physiol. Mol. Plant Pathol., 100(1), 35-40. doi:10.1016/j.pmpp.2017.05.008

Silva, A. G., Almeida, D. L., Ronchi, S. N., Bento, A. C., Scherer, R., Ramos, A. C. et al. (2010). The essential oil of Brazilian pepper, Schinus terebinthifolia Raddi in larval control of Stegomyia aegypti (Linnaeus, 1762). Parasites \& Vectors, 3(79), 1-7. doi:10.1186/1756-3305-3-79

Silva, A. M. A., Silva, H. C., Monteiro, A. O., Lemos, T. L. G., Souza, S. M., Militão, G. C. G. et al. (2020). Chemical composition, larvicidal and cytotoxic activities of the leaf essential oil of Bauhinia cheilantha (Bong.) Steud. S. Afr. J. Bot., 131(1), 369-73. doi:10.1016/j.sajb.2020.03.011

Silva, M. F. R., Bezerra-Silva, P. C., Lira, C. S., Albuquerque, B. N. L., Agra Neto, A. C., Pontual, E. V. et al. (2016). Composition and biological activities of the essential oil of Piper corcovadensis (Miq.) C. DC (Piperaceae). Exp. Parasitol., 165(1), 64-70. doi:10.1016/j.exppara.2016.03.017

Silva, P. T., Santos, H. S., Teixeira, A. M. R., Bandeira, P. N., Holanda, C. L., Vale, J. P. C. et al. (2019). Seasonal variation in the chemical composition and larvicidal activity against Aedes aegypti of essential oils from Vitex gardneriana Schauer. S. Afr. J. Bot., 124(1), 329-32. doi:10.1016/j.sajb.2019.04.036

Silva, R. C. S., Milet-Pinheiro, P., Silva, P. C. B., Silva, A. G., Silva, M. V., Navarro, D. M. A. F. et al. (2015). (E)-Caryophyllene and $\alpha$-Humulene: Aedes aegypti oviposition detrents elucidated by gas chromatography-electrophysiological assay of Commiphora leptophloeos leaf oil. Plos One, 10(12), 1-14. doi:10.1371/journal.pone.0144586

Silva, W. J., Dória, G. A. A., Maia, R. T., Nunes, R. S., Carvalho, G. A., Blank, A. F. et al. (2007). Effects of essential oils on Aedes aegypti larvae: alternatives to environmentally safe insecticides. Bioresour. Technol., 99(8), 3251-5. doi:10.1016/j.biortech.2007.05.064

Soares, A. S. (2007). Lamiaceae in Rio Grande do Norte: taxonomy and conservation status. Master's thesis, Fed. Univ. Rio Gd Norte, Natal - RN, Brazil. https://repositorio.ufrn.br/bitstream/123456789/23464/1/ArthurDeSouzaSoares_DISSERT.pdf

Strub, D. J., Balcerzak, L., Niewiadomska, M., Kula, J., Sikora, M., Gibka, J. et al. (2014). Stereochemistry of terpene derivatives. Part 8: synthesis of novel terpenoids from (1S,4R)- and (1R,4S)-fenchone and their comparative odour characteristics. Asymmetry, 25(13-14), 1038-45. doi:10.1016/j.tetasy.2014.06.012

Sucen - Supt. Nac. Controle Endem. (2001). Segurança em controle químico de vetores. https://portalidea.com.br/cursos/396d45d6e40914b34e25fd98ed99d702.pdf

Trindade, F. T. T., Stabeli, R. G., Pereira, A. A., Facundo, V. A. \& Almeida e Silva, A. (2013). Copaifera multijuga ethanolic extracts, oil resin, and its derivatives display larvicidal activity against Anopheles darlingi and Aedes aegypti (Diptera: Culicidae). Rev. Bras. Farmacogn., 23(3), 464-70. doi:10.1590/S0102-695X2013005000038

Voris, D. G. R., Dias, L. S., Lima, J. A., Lima, K. S. C., Lima, J. B. P. \& Lima, A. L. S. (2018). Evaluation of larvicidal, adulticidal, and anticholinesterase activities of essential oils of Illicium verum Hook. f., Pimenta dioica (L.) Merr., and Myristica fragrans Houtt. against Zika virus vectors. Environ. Sci. Pollut. Res., 25(23), 22541-51. doi:10.1007/s11356-018-2362-y 